\title{
The Socialism of Frantz Fanon: A Theory for the Rehabilitation of Subjugated People
}

\section{Malick Diagne \\ ORCID iD: $\underline{\text { https://orcid.org/0000-0002-5410-9648 }}$}

\begin{abstract}
From Fanon's perspective of deconstructing the logics of expropriation and alienation specific to the colonial system, it is first of all a question of showing that the struggle for independence has not escaped the problematic of the class struggle. Thus, on the strength of this observation, Fanon's socialism mobilizes the socialist project for the total liberation of colonized societies. Suddenly Fanon's thought appears as a complex and powerless arsenal capable of decompartmentalising territories, bodies, minds, concepts and knowledge, and of unlocking the frameworks of Marxist Analysis confined in the prism of bourgeoisie / proletariat domination to open up to a humanism built around the nation, independence and freedom.
\end{abstract}

Keywords: Colonised people, independent nations, colonised countries, modernity

\section{Introduction}

There is, in Frantz Fanon's thought, a specific historicity that characterises the formerly colonised people and which should push them to the invention of a new historical subject capable of carrying, in all its radicality, the work necessary for the survival of the newly independent nations. This is why there is a break, in colonised countries, especially in Africa, from the form of modernity witch the West wanted to impose on the rest of the world.

Euromodernity has turned out to be a system of dispossession that destroys all the creative potentials of the subordinated people. In other words, 


\section{Malick Diagne}

this modernity, which found its champions in the Enlightenment movement and which was to be not only the framework of liberation but also of human development, gave birth, in the colonised regions, to a violent and iniquitous system of exploitation and negation of subjected populations. In short, these were all the things that socialism combats in its fundamental principles, whatever the referents or the theoretical obedience. Although in general, during the colonial period, the apathy of Africans against the orderly system of Euromodern administration was seen by the colonists and their specialists as a characteristic trait of the savage, poorly educated and lazy, we can today, with hindsight, see it as, a strategy of resistance, an anti-system attitude specific to Africans.

For Fanon, because of this particular historical weight, radicalism must be the framework from which the subject societies struggle and build their freedom; a creative freedom of a new humanity. He explains this point of view, in a programmatic way, in his speech, presented at the Second Congress of Black Writers and Artists of March - April 1959. He said:

In a colonised country the most elementary, the most brutal, the most undifferentiated is the most fervent and most effective form of defense of national culture.

Thus, throughout the decades of independence that began at the end of the 1950s, the dominant feature of societal dynamics in Africa is the struggle, as Achille Mbembe says, which,

aims to produce life, to overthrow the hierarchies instituted by those who have become accustomed to winning without being right, 'absolute violence' playing, in this work, a detoxifying and instituting function.

We can, therefore, say that Fanon's position on socialism finds its foundation in the need to fight for the values and cultures specific to the dominated people. Philippe Lucas (1971) speaks of 'betting on the spontaneity of the masses' through a framework that does not necessarily have to follow the contours of socialist systems such as a certain interpretation or 'application' of Marxism [that proponents] wanted to impose in Africa. Amady Aly Dieng (2011: 188), with Fanon, castigates, 
a whole host of socialists in Black Africa for disguising the thought of Karl Marx to sing to us about the saving virtues of their African ways of socialism which are in reality the different ways of a colonial capitalism that no longer dares to speak its name.

In this article, I will start from the Fanonian analysis of the colonial system, which he considers as a violent and iniquitous system of expropriation, and negation of the humanity of the colonised people, to show how Fanon's radical position and his socialist perspective find their explanation in his humanism through the project of liberation and rehabilitation of colonised people.

\section{Colonialism as a Violent System of Expropriation, Alienation and Dispossession of Colonised People}

Colonisation as a system of domination is undoubtedly one of the projects of subjugation that has most influenced historical experiences and social practices in Africa. Both its breadth and depth were a powerful marker in the history of the Continent. Maurice Kamto (1987: 207) speaks of historical experiences and particular social practices that 'are still developing their effects today'. To this, we should add: its perverse effects. Even if the colonial policy, from its beginnings to the Second World War, developed in a wobbly balance between the theory of assimilation and that of association, between direct administration and a permanent recourse to traditional hierarchies, all under the iron fist of a highly centralised administration, it has always been clear about the status of African populations.

For the colonial policy, the natives should remain administered willynilly. It has never been in favour of the advent of African social movements, let alone the awakening of a political consciousness among Africans. It has always stifled all forms of action, whether protest or other forms of political activity that could lead to revolts or questioning the operating system in place, even in the most trivial aspects. In other words, despite the ideology of its promoters who defended a civilising mission, colonialism in fact has revealed itself as a powerful alienating and expropriating system for subjugated societies. It is from this perspective that Thierry Michalon (1984: 136) writes about the colonial heritage: 
This heritage is surely one of the most serious handicaps that the countries of Africa still suffer. Like a bicycle without half its chain, the state cannot turn because it lacks the political half of the belt. Reduced to a simple administration, the state is surprised at its powerlessness, when this is not surprising: men find it difficult to comply with rules they did not help to develop!

Indeed, in addition to the negation of the being of the colonised, in particular the black person (Fanon 2011), the colonial system denies the existence of specifically indigenous political referents of the subject societies. The Negro does not have the same human dignity as the white settler, but local societies also do not enjoy any political consideration. Thus, the defeated traditional chief and his descendants do not enjoy considerable political recognition. They have mere auxiliary roles that reduce them to mere performers of lesser tasks in the overall management of the company.

Faced with the poverty of the political perspective of the colonised people of Africa that he saw, as The Provincial Government of the Algerian Republic (GPRA) ambassador, Fanon worries, gets angry, and takes a firm stand against the internal autonomy proposed by General de Gaulle. This is why, after participating in the struggle for the emancipation of black people through the negritude movement, Fanon takes a new path for the liberation of colonised societies. It is thus part of a Third World perspective that allows it, on the theoretical and practical levels, to take charge of the problems linked to the liberation of people, to racial segregation, to colonialism in Africa, Asia and, South America. This new positioning allows it to go beyond the perspective of the black individual (the 'I' of Black Skin, White Masks) to be liberated or de-alienated in order to move towards the collective consciousness (the 'We' of the Damned of the Earth) that must promote the advent of the political nation, the one and only liberating framework. This is the meaning of his fight on Algerian soil.

In Sociology of a Revolution, Fanon gave himself a well-defined political objective: to bring about a new world through [the struggle for] freedom: 'We want to show ... that on Algerian soil a new society was born' (Mbembe in Fanon 2011: 13). Breaking with the movement of negritude, Fanon is in search of an 'authentic community' and combatant, from which will spring, as Achille Mbembé notes, 
an unprecedented human subject capable of inhabiting the world and of sharing it so that the possibilities of communication and reciprocity - without which neither the dialectic of recognition nor human language - can be restored (in Fanon 2011:10).

In this new world, the peasantry, as an authentic community and fighting force, is the spearhead capable of destroying the system of domination in place. The revolt thus becomes the creation of a new man, continues Mbembé, 'an almost indefinable subject, always left behind because never finished, like a gap that resists the law, even any limit' (in Fanon 2011:10).

It is this liberation project that allows Fanon to become part of posterity through the creation of this new man who is characterised by creative openness as his life was; he who was born in Martinique and died as an Algerian national hero. Fanon, due to his biography, did not have enough time to dwell on conceptual circumscriptions. Rather, he had strong intuitions that secured his place in posterity in terms of understanding the existing world and exploring the future of colonised societies and colonial heritage. Thus, from Fanon's point of view, one of the most significant aspects of the colonial heritage in Africa is the legacy of a personalised power built around what Yves Bénot (1975: 76) called 'a lower middle class'. This bourgeois woman, made her own the struggle for the independence of the former colonial territories, which, despite her peculiarity, would not escape the problem of class domination. Moreover, it is at this level that Frantz Fanon's analysis takes on its full meaning and vigour through the refusal to reduce the colonial question to the sole dimension of the class struggle such as a certain Marxist vulgate wanted and whose sterile formulation can be found in Lenin's formula: 'imperialism as the supreme stage of capitalism'.

\section{Fanon's Radicalism: A Renewed Bet on the Human}

Fanon starts from an observation that founds his radicalism, the Manichean nature of the colonial system, which he describes as follows: The colonial world is a Manichaean world. It is not enough for the colonist to limit physically, that is to say with the help of his police and his gendarmerie, the space of the colonised. As if to illustrate the totalitarian character of colonial exploitation, the colonist makes the colonised a sort of quintessential evil. Colonised society is not only described as a society without values. It is not 


\section{Malick Diagne}

enough for the settler to assert that values have deserted, or better never inhabited, the colonised world. The native is declared impermeable to ethics, not only the absence of values, but also the negation of values (Fanon, 2011: 455 - 456). With Fanon there is a form of radicalism necessary to get the colonised people out of the iniquitous system of subjugation and negation in which they are immersed. And for that, all the means are good: 'all the revolts, all the desperate acts, all the attempts aborted or drowned in blood' (Fanon 1961: 142). The power of the outburst of revolt of the colonised is commensurate with 'the aggressiveness which permeated the victorious confrontation of these values with the ways of life or thought of the colonised' (Fanon 2011: 457).

Fanon is part of a form of radicalism that operates within a historical context where insubordination, whatever it may be, becomes a liberating value in that it allows, dialectically through negation, the advent of a new world. For there is a need to supplant the colonial world with a world where the colonised, who discovers the fullness of their long denied humanity, assume themselves as masters of their own destiny through the existence of an independent nation.

With Fanon, the revolution, which reaches beyond socialism in Africa and elsewhere, demands overcoming the opposition/ contradiction between the individual and the common, between the particular and the collective. Because for him, from the point of view of the African, he speaks of the 'African spirit', life and death, the real and the imaginary, the high and the low, the past and the future cease to exist, to be perceived contradictorily. This position allows the revolt to become part of the action by taking charge of a multitude of referents that are contradictory only in appearance. On the contrary, all these references find their ferment and their common basis in the radical nature of the action to be taken to liberate humanity through the struggle of the oppressed people.

Fanon thus justifies his radical perspective by his perception of the colonial system, which he considers to be a framework of total violence where the individual is there only for the need for its perpetuation. In this system, the black person is discredited even in his or her own consciousness, as Fanon (2011: 66) explains in this connection:

If there is an inferiority complex, it is as a result of a double process:

- economically first; and

- by internalisation or, better, epidermisation of this inferiority, then. 
Fanon does not analyse, as in Engels, the foundations of violence solely from an economic point of view. It places them in a global and complex framework in which a multitude of factors intertwine without necessarily contradicting each other. Better still, it gives a nodal value to violence in the structuring of dominated societies; it is both 'average and done' (Fanon, 2011: 451-506). For him, the system of violence put in place, which is at the beginning and throughout the colonial practice, must be turned against the latter to overcome it and in the same dynamic bring about a new world. Amadou Aly Dieng (2011: 185) describes this weight of violence in Fanon's analysis, not without criticising it. He notes, as follows:

Fanon brings very interesting views on the forms that violence takes over the course of history of oppressed countries. During the first phase, violence characterised the colonial period. In the second phase, it is internalised and directed against the colonised themselves in incessant tribal struggles. In the third phase, it is directed against the coloniser.

It is true that Fanon did not take care to go all the way in his analysis of violence to bring out all the consequences in the structuring of colonised societies and in their future. But there is this determination to deconstruct the totalitarian logic of the system, which relies on end-to-end violence. Fanon is not unaware of the question of social relations and its impact on the phenomenon of violence. In all his work, the phenomenon of violence is approached from the many hats Fanon wears: a Martinican, therefore born colonised; a psychiatrist, therefore analyst, phenomenologist, therefore Hegelian dialectician then Marxist and a little Sartrean; an Algerian liberation fighter, therefore Third-Worldist and universalist. All these dimensions of his character meant that Fanon did not have the time for, and also did not want to get bogged down in, theoretical over-determinations that would prevent him from making his pen a weapon against oppression, a tool of liberation, and an instrument in the service of the human cause. Fanon, by setting in motion the phagocyte of revolt and all creative energies, blocked all dark points (alienation, assimilation, the inferiority complex, defeatism, identity withdrawal, racism, reformism) and opened all the prospects for the new man (disalienation, open-mindedness, multiculturalism, Third Worldism, universalism). 
For Fanon, everything must be mobilised, including our own being, for the only cause that is worthwhile is that of freedom, as noted by Alice Cherki (2011: 292), who reported this statement by Fanon, made from his hospital bed - in the process of throwing his last pawn in the fight of his life: 'We are nothing on earth if we are not first of all the slaves of a cause, of the cause of the peoples, the cause of justice and of freedom'. From then on with Fanon everything is held together, revolt, rejection, indignation, revolution, liberation, creation; everything refers to freedom. Because man, who has known this world, where people have been oppressed for so long, can only be renewed through freedom.

\section{Socialism as a Means of Struggle for the Values and Cultures Specific to the Dominated People}

To understand Fanon's socialist perspective, his work must be read from a perspective that allows for an analysis grid of the 'social question' with theoretical and political tools capable of shedding light on the complex interweaving of multiple social relations between class, gender, background (city centre versus suburb, city versus countryside, workers versus peasants) in a context of colonial domination. Today, with the heavy colonial liabilities, in globalised urban centres as well as in the peripheral suburbs of the former colonies, especially in Africa, social relations of an economic, religious, gender-based and sometimes racial nature (with the regrouping of populations in certain residential neighbourhoods) seem more than ever to fit into this dominant/dominated pattern well circumscribed by Fanon. The characteristics of the situations of domination and the dynamics that are set up give a certain topicality to Fanon, through for example, the process of politicisation of the forms of resistance of subordinate groups (resistance passing through religion, sports, music, popular culture, defence of the land).

Fanon, as an integral thinker in the sense that his writings testify to the desire to decompartmentalise territories, bodies, concepts, and knowledge, allows us to unlock the frameworks of Marxist analysis confined in the prism of bourgeoisie/proletariat schema. There is, thus, the peasantry in the colonies of Africa, which is numerically the most important category and whose combat experience, as was the case in Algeria, can be decisive in the liberation struggle and the constitution of the nation. And beyond the theoretical borders of popularised Marxism, today other lines of demarcation appear that cross urban 
areas (city centre/suburbs), bodies (young/old or male/female), territories (cities/campaigns), disciplines (football/wrestling), knowledge (Westernised/ Arabist intellectuals). We can, therefore, speak of new categories with Fanon in the understanding of social reality and unprecedented dynamics, in any case specific to African societies, for political practice on which no dogmatic and rigid analysis of Marxism can shed light.

More than any other revolutionary theory, Fanon's thought is an antisystem surgically directed against the colonial operating system. This, moreover, explains the importance he attaches to the peasantry, as the spearhead of the Algerian revolution, through their numerical importance and their weight in the liberation struggle. We can speak of a new reinterpretation of the eleventh thesis on Feuerbach as Fanon posed it in these terms by postulating a tumble of the 'steps of History': 'It is no longer a question of knowing the world, but to transform it' (2011: 71). According to Fanon, such a situation requires taking charge of a culture, not fixed but relieved of the weight of fixations of identity and oriented towards 'invention in existence' (2011: 250). In other words, as Fanon says in the last lines of Black Skin, White Masks: 'it is by going beyond historical, instrumental data, that I introduce the cycle of my freedom' (ibid). The question of freedom is therefore inseparable from the question of social justice and, this, certain social groups (the Algerian peasants in particular) understood well and integrated it in their modes of popular action, through concrete initiatives ranging from: raising awareness for registration on the electoral rolls to lucrative activities organised around urban music; from the struggle through to the defence of human rights, monitoring of the conduct of elections, to villagers who defend their land against multinational corporation and other businessmen.

Through the peasantry, it is in the people that we trust to carry out the revolution and the appropriate reforms for the establishment of the new nation. Fanon (2011: 574) explains and gives the example of Algeria in this regard: 'However, it turns out that the people, when they are invited to lead the country, do not delay but accelerate the movement .... We Algerians, during this war, had the opportunity, the happiness to put our finger on a number of things'. With the revolution, Fanon's goal is no longer just to deal with an insane subject and free him from the bourgeois capitalist system. Now it is a matter of liberating the entire colonised society and building a free nation through the disalienation of the submissive people of all continents. And for this project his only certainty is the path of total revolution, the radical change that will 


\section{Malick Diagne}

'break the backs of colonialism'. For Fanon, there is only national liberation which involves total revolution. Because, he maintains:

Colonial domination, as it was total and simplifying, dramatically disrupted the cultural existence of the submissive people. The negation of national reality, the new legal relations introduced by the occupying power, the rejection of the periphery by the colonial society of the natives and their customs, the expropriation, the systematic enslavement of men and women make this cultural obliteration possible (Fanon 2011: 613).

From a materialist perspective, Fanon broadens the question of domination to include relations specific to indigenous societies, giving racial and sexual questions a theoretical dignity alongside that of class struggle. The scope of Fanon's reflection is to have restored, to its proper extent, the political dimension of these acts of domination that run through colonised African societies that are not systematically arranged by colonial logic. Thus, through the formulation of the eleventh Marxian thesis on Feuerbach, from the first lines of Black Skin, White Masks, Fanon (2011: 63 - 251) reintegrates the question of the transformation of colonised societies for an authentic liberation of the African who must not come out of the colonial yoke to enter a more underhanded formation, because keeping the inherent flaws of the capitalist system of exploitation without retaining the 'fallout' of a viable formal system. Indeed, the history of social demands, in the former French colonies of black Africa, is incomprehensible if it is not integrated into the general framework of the movements of struggle for political emancipation, even if or when the struggle is not immediately apparent. Because, if the social demands were originally the work of settlers who, although attached to African soil, made no allusion to local autonomy, later, with the arrival of black leaders, they gradually took on a turn of struggle for independence. To understand the importance and role of these movements in the socio-political evolution of Africa, each of these two aspects of the advent of the protest phenomenon should be considered as objectively as possible ${ }^{1}$.

However, beyond this double dimension, it is the congenital incapacity of this bourgeoisie that attracts Fanon's attention in the liberation struggle. This bourgeoisie is characterised by the umbilical link it maintains with the colonial system. It is unable to free itself from the logic of

${ }^{1}$ On this question, we can cite Girardet, R. 1972. L'idée coloniale en France. Paris: Ed. La Table Ronde. 
intermediation that made it appear in the colonial context. And in general, the elites from this bourgeoisie or the indigenous proletariat remain frozen in the predatory frameworks built by the colonial system to the detriment of a real policy of liberation and national construction. It is 'businessism', through schemes and intrigues, which constitutes its modus operandi and not the entrepreneurial spirit likely to lead a country towards social and economic development. Fanon describes this bourgeoisie, which seized power in Africa at the time of independence, as an 'underdeveloped bourgeoisie' essentially oriented towards the economy of intermediaries and not of radical transformation of the economic structure ${ }^{2}$. He sees in this bourgeoisie a retrograde and pernicious force in that it constitutes, under the aegis of the imperial powers that provide it with money, arms, technicians, and training, a brake against 'the masses' revolutionary aspirations' (Dieng 2011: 192). For Fanon, it is only a specific social layer, which he qualifies as 'honest intellectuals, without very precise political ideas who instinctively mistrust this race for posts and prebends' (2011). Les Damnés de la Terre will be able to carry the decisive combat to the popular masses through a healthy orientation of the nation. Here his approach is close to that of Lenin on the organisation of a revolutionary leadership capable of raising the people, broadening their thinking and organising them (Azar 2014: 84) ${ }^{3}$.

Socialism, according to Fanon is therefore not a scientific affair, much less of a political apparatus sclerotic in ideological certainties. Rather, there needs to be an awareness of the need for liberation by a few determined elements that, in doing so, descend on popular ground. Philippe Lucas (1971: 150) circumscribes it as follows:

It is this real movement grasped by Fanon that socially founds the WeComrades-of-the-Three-Continents, which designates in the bourgeois castes its immediate enemy and makes the critical unity of Fanon's analysis. The exaltation of the spontaneous means the rehabilitation of

\footnotetext{
${ }^{2}$ Without having exact data, we can cite the residential districts of Mamelles and Almadies in Dakar where the presence of large numbers of Westerners and mixed couples is quite visible.

${ }^{3}$ Lenin's text, published in 1917, later published in French in 1925: Lenin, 1925, Imperialism, the Last Stage of Capitalism, Paris, Librairie de l'Humanité.
} 
a praxis of struggle against a nationalism without content: that of the traditional nationalist parties, that of the bourgeois castes - even of an opportunist urban proletariat; in doing so, it only represents a moment of Fanon's approach in The Damned of the Earth. The final phase, not to say stage, is the movement that allows the intellectual, aware of his historical role, to adhere to the spontaneous revolt of the masses, to achieve self-recognition (by rehabilitating its culture without shutting itself in) and to become a historical subject by bringing about a new humanism around the nation, freedom and independence ${ }^{4}$.

\section{Conclusion}

In total, it appears in Fanon's work, as Michael Azar (2014: 90) points out, a deep tension between the concepts belonging to the Hegelian-Marxist tradition (alienation, dialectics, fraternity, recognition, the new man, atonement, action, etc.) and notions relating to psychoanalysis (the unconscious, envy, desire, imitation, ambivalence, etc.), all never really well circumscribed. Fanon is a phenomenologist through his strong intuitions and his keen sense of the facts, existentialist through the weight he gives to action, analyst through his profession and his study of the mechanisms of alienation as pathologies of civilisation (Renault: 2012), and dialectical Marxist by the creative role that he confers on the revolution. But above all, a freedom fighter he is, and this is what makes him an integral thinker who will espouse socialism, a socialism that will have as its spear the peasant masses through the revolution. One can challenge this point of view, like Amady Aly Dieng (2011: 195), as weak who protests that 'Fanon cannot quote us a revolution with peasant direction which succeeded in the past or the present'. But once again, as someone very close to Sartre, he inscribes being in the existent accomplished by act, by actions. And Fanon, noting the embryonic and opportunist aspect of the proletariat of the

${ }^{4}$ On socialism itself, it is more prudent, with Fanon, to speak of a socialist perspective because, as with all the other aspects of his work, his life and his struggle, which are as one, he passes without too much focus on definitional frameworks. The priority for him is action because it is action that determines reality, especially social reality. It is not surprising that he is close to Sartre who, more than a mentor, was an accomplice in this life built around the quest for freedom. 
African colonies at the same time, set his sights on the category that is numerically most important to make history and create new humanity. As an integral man, Fanon's political struggle is at the same time his theoretical work and his psychiatric practice. It is about liberating oppressed people, especially Africans. But in his vision, national independence, as it began, was heading straight for a fiasco, emptying itself of its emancipatory and liberating dimensions.

History today seems to prove him right in terms of liberation and the building of viable economic and social structures on a nationwide scale. Indeed, his work, The Damned of the Earth, seems to be a premonitory book in the face of the struggles for power, tribalism, and regionalism of all kinds that are in the news in Africa. Fanon is indeed an integral thinker in that his thought and his action are one. If he did not explore all areas that affect man and society, it is because he was in a hurry. He was pressed by the urgency to decolonise minds and facts; he was also pressed by existence, which he knew to be fleeting and brief. He aimed to fully decolonise man through the liberation of oppressed people, a huge and enduring mission. Yet he knew he was dying; he lived for only 36 years. A short life, it could be argued, but a full life. He wrote Black Skin, White Masks, at only 25 and his powerful plea for humanity, The Damned of the Earth, at 35, an age when the individual is still usually only looking out for himself. Young, he was and has remained, but tall and visionary, he will continue to be by the force of his arguments and his intuitions. Revolutionary, he remains through his testament that constitutes this powerful work which allows today, and certainly tomorrow, to invigorate the revolutionary potential of the popular dynamics of certain social categories, until then left stranded by the locomotive of globalisation: the youth and African women who die by the thousands in the oceans and deserts of the world, the peasant women who continue to collapse under the drudgery of the harsh countryside, the African peasants who are deprived of their land, simply living the fate of the 'damned of the Earth'.

\section{References}

Azar, M. \& Y. Rouvière 2014. Comprendre Fanon: Vers un nouvel humanisme. Paris: Editions Max Milo.

Bentouhami, H. 2014. De Gramsci à Fanon. Actuel Marx 55.

https://doi.org/10.3917/amx.055.0099. 
Cherki, A. 2011. Frantz Fanon: Portrait. Paris: Editions du Seuil.

Dieng, A.A. 2011. Mémoires d'un étudiant africain, vol. II, De l'Université de Paris à mon retour au Sénégal 1960-1967. Dakar: CODESRIA. https://doi.org/10.2307/j.ctvk3gnw3.

Fanon, F. 2011. Oeuvres. Paris: Editions La Découverte.

Fanon, F. 1961. Les Damnés de la Terre. Paris: Editions Maspero.

Girardet, R. 1972. L'idée coloniale en France. Paris: Ed. La Table ronde.

Gordon, L.R. 2008. Décoloniser le savoir à la suite de Fanon. Tumultes 31: 103 - 123. https://doi.org/10.3917/tumu.031.0103.

Kamto, M. 1987. Pouvoir et droit en Afrique Noir. Essai sur les fondements du constitutionnalisme dans les Etats d'Afrique Noire, Francophone. Paris: LGDJ.

Lenin, V. 1925. L’impérialisme, dernière étape du Capitalisme. Paris: Librairie de l'Humanité.

Lucas, P. 1971. Sociologie de Frantz Fanon: Contribution à une anthropologie de la liberation. Alger: Société Nationale d'Edition et de Diffusion.

Macey, D. 2011. Frantz Fanon: Une vie. (Traduit de l'anglais par Christophe et Jaquet et Marc Saint-Upéry.) Paris: La Découverte.

Mbembe, J-A. 2011. Preface. In Fanon, F. Oeuvres. Paris: Editions La Découverte.

Michalon, T. 1984. Quel État pour l'Afrique? Préface de Gérard Conac. Paris: L'Harmattan.

Malick Diagne

Head of Department, Philosophy Université Cheikh Anta Diop [UCAD] Member of Research Laboratory GIRCI and LERPSCAM at UCAD Visiting Professor, Radboud University, Nimègue aux Pays-Bas diagnemalick@yahoo.fr 